\title{
Modification of Acid Sites in ZSM-5 by Ion-exchange: An in-situ FTIR Study
}

\author{
Weiqiang $\mathrm{Wu}^{\dagger}$ and Eric Weitz ${ }^{\dagger *}$
}

'Institute for Catalysis in Energy Processes and Center for Catalysis and Surface Science tDepartment of Chemistry, Northwestern University,

Evanston, Illinois 60208, United States

(C) 2014. This manuscript version is made available under the Elsevier user license http://www.elsevier.com/open-access/userlicense/1.0/ 


\begin{abstract}
A study of the acid sites in $\mathrm{M}^{\mathrm{n}+}-\mathrm{ZSM}-5$ zeolites $\left(\mathrm{M}^{\mathrm{n}+}=\mathrm{H}^{+}, \mathrm{Al}^{3+}, \mathrm{Ca}^{2+}\right.$, and $\left.\mathrm{Ba}^{2+}\right)$, synthesized by ion-exchange from the $\mathrm{NH}_{4}{ }^{+}$form, has been carried out using X-ray diffraction, ${ }^{27} \mathrm{Al}$ MAS NMR, and in-situ FTIR spectroscopy. X-ray diffraction data indicate that the crystalline structure of ZSM-5 is maintained on ion-exchange. ${ }^{27} \mathrm{Al}$ MAS NMR spectroscopy confirms that Lewis acid sites in all of the $\mathrm{M}^{\mathrm{n}+}-\mathrm{ZSM}-5$ zeolites are mainly located on the tetrahedral aluminum atoms in the zeolite framework. However, octahedral extra-framework aluminum is another source of Lewis acid sites in $\mathrm{H}^{+}-\mathrm{ZSM}-5$ and $\mathrm{Al}^{3+}-\mathrm{ZSM}-5$. Brønsted acid sites are identified as originating from the hydroxyl groups that bridge $\mathrm{Al}$ and $\mathrm{Si}$ atoms. The acid sites in $\mathrm{M}^{\mathrm{n}+}-\mathrm{ZSM}-5$ have been characterized by in-situ FTIR spectroscopy with pyridine as the probe molecule. FTIR spectroscopy demonstrated that the number of accessible acid sites and ratio of Lewis to Brønsted acid sites in $\mathrm{M}^{\mathrm{n}+}-\mathrm{ZSM}-5$ can be effectively modified by ion-exchange. The number of acid sites in $\mathrm{M}^{\mathrm{n}+}-\mathrm{ZSM}-5$ increases in the same order as the acidity of cations with $\mathrm{Ba}^{2+}<\mathrm{Ca}^{2+}$ $<\mathrm{NH}_{4}^{+}<\mathrm{Al}^{3+}<\mathrm{H}^{+}$. Though the strength of both Lewis and Brønsted acid sites is virtually identical for all $\mathrm{M}^{\mathrm{n}+}-\mathrm{ZSM}-5$ zeolites, the ratio of Brønsted to Lewis acid sites varies as a result of the loaded cation. In addition, modification of acid sites in $\mathrm{M}^{\mathrm{n}+}-\mathrm{ZMS}$ 5 by loading different cations is discussed in terms of the accessibility of the surface of the zeolite channels and the reactivity of the cations with Brønsted acid hydroxyls. We conclude that larger cations can effectively constrict the zeolite channels and impede the ability of pyridine to access acid sites on the surface of the channels.
\end{abstract}




\section{Introduction}

Brønsted and Lewis acid sites in the framework of zeolite-based catalysts play an important role as active sites for various processes in refining and petroleum processing.[1-4] For example, Brønsted acid sites of ZSM-5 have been widely exploited for paraffin isomerization,[5] conversion of methanol to gasoline and olefins,[6, 7] ethylbenzene production,[4] and the Chichibabin condensation.[8] Lewis acid sites of hydrothermally pretreated ZSM-5 control the catalytic activity for hydroxylation of aromatics to their corresponding phenols.[9] Lewis acid sites in zeolite $\mathrm{Y}$ have also been shown to be efficient for the isomerization of glucose to fructose in alcohols and aqueous media.[10] Nevertheless, for some applications a high degree of zeolite acidity can produce undesired reactions such as cracking.[11] For this reason it is highly desirable to be able to control zeolite acidity. Methods that have been widely explored involve modifying the Si/Al ratio through dealumination[12-15] or ion-exchange.[16-19] It has been reported that these procedures can be used to control the formation and rearrangement of carbonium ions in many hydrocarbon reactions.[20, 21]

Since zeolite acid sites are involved in acid-catalyzed hydrocarbon reactions, characterization and measurement of the acidity of zeolites, including the number, type, origin, and strength of the acid sites, is of scientific and practical interest. There are many methods that have been used to characterize the acidity of solid acid catalysts, of which temperature-programmed desorption (TPD)[2, 12, 22-24] and FTIR spectroscopy [2, 12, 25-27] have been widely used. Information on the strength of solid acid sites, as determined by the strength of the probe molecule - acid site bond, can be readily derived from TPD data. However, TPD cannot intrinsically distinguish between Brønsted and Lewis acid sites. Additionally, extraction of quantitative information from TPD data in an explicit form depends on a valid interpretation of the TPD data in terms of a correlation between the TPD profiles and different acid sites. There is an excellent review about TPD method that explores these issues.[28]

FTIR spectroscopy has proved to be a very powerful tool for identifying the nature (type and strength) of acid sites.[2, 29-32] By employing probe molecules, such as ammonia, acetonitrile and pyridine, FTIR spectroscopy can be used to easily discriminate 
between Brønsted and Lewis acids. Acid strength can be estimated from the intensity profile of desorbed molecules versus temperature. An experimental determination of the integrated molar extinction coefficients of bound pyridine can be used to provide a reliable estimate the number of acid sites.[29, 30] FTIR spectroscopy with probe molecules has been used in the determination of the number of acid sites for cation modified ZSM-5.[33-35] For instance, Sachtler et al. synthesized Zn/Ga/Fe-ZSM-5 loaded with acidic cations $(\mathrm{Zn}, \mathrm{Ga}$, and $\mathrm{Fe})$ and investigated the effect of these metal cations on Brønsted acid sites of ZSM-5.[27] Coelho et al. explored the influence of basic sodium ions on the number and strength of acid sites.[18] TPD with FTIR spectroscopy have been combined to provide comprehensive information on acidity. For example, Niwa and co-workers reported that IR combined with $\mathrm{NH}_{3}$-TPD simultaneously provides information on the strength and quantity of acid sites of zeolites[23, 24, 36, 37] and $\mathrm{ZrO}_{2} \cdot[38]$

Studies that explore how the cations affect the acidity of ion-exchanged zeolites are rare. To our knowledge, there have been no systematic quantitative studies of the effect of cation acidity on the acid sites of zeolites, i.e., the number of total acid sites, the distribution (or ratio) of Brønsted and Lewis acid sites, and the strength of the acid sites. In this work, a series of $\mathrm{M}^{\mathrm{n}+}-\mathrm{ZSM}-5\left(\mathrm{M}^{\mathrm{n}+}=\mathrm{H}^{+}, \mathrm{NH}_{4}{ }^{+}, \mathrm{Al}^{3+}, \mathrm{Ca}^{2+}\right.$, and $\left.\mathrm{Ba}^{2+}\right)$, where the cations have different Lewis acidities has been synthesized via ion-exchange methods and characterized by XRD, ${ }^{27} \mathrm{Al}$ MAS NMR, and in-situ FTIR spectroscopy. We also prepare $\mathrm{H}^{+}-\mathrm{ZSM}-5$ via in-situ calcination of the ammonia form of ZSM-5 which allows us to compare this material to $\mathrm{H}^{+}-\mathrm{ZSM}-5$ produced by ion exchange. Employing in-situ FTIR spectroscopy with a pyridine probe molecule, the individual Brønsted and Lewis acid sites in $\mathrm{M}^{\mathrm{n}+}$-ZSM-5 have been identified and quantified. We also discuss the mechanism by which the number of accessible acidic sites is modified as a function of the nature of the cation and propose a model by which loaded cations affect the acidity of zeolites. We anticipate that this work will provide insights into the fabrication of new $\mathrm{M}^{\mathrm{n}+}$-ZSM-5 catalysts with desirable levels of the appropriate type of acid sites (Brønsted or Lewis) for a given reaction. 


\section{Experimental}

\subsection{Synthesis and in-situ pretreatments}

$\mathrm{NH}_{4}{ }^{+}$-ZSM-5 $(\mathrm{Si} / \mathrm{Al}=80)$ was purchased from Sigma-Aldrich and used without further purification. A series of metal cation-functionalized $\mathrm{M}^{\mathrm{n}+}-\mathrm{ZSM}-5\left(\mathrm{M}^{\mathrm{n}+}=\mathrm{Al}^{3+}\right.$, $\mathrm{Ca}^{2+}$, and $\mathrm{Ba}^{2+}$ ) and $\mathrm{H}^{+}$-ZSM-5 zeolites were prepared by a standard ion-exchange procedure using aqueous solutions of the each nitrate salt or nitric acid.[39] Typically, 1.5 $\mathrm{g}$ of $\mathrm{NH}_{4}{ }^{+}$-ZSM-5 was suspended in $50 \mathrm{~mL}$ of $2.0 \mathrm{M}$ aqueous solution of each nitrate salt (nitric acid for $\mathrm{H}^{+}$-ZSM-5) and was stirred at $80{ }^{\circ} \mathrm{C}$ for $4 \mathrm{~h}$, followed by washing with deionized water until no free ions remained, centrifugation, and then drying in vacuum at $120{ }^{\circ} \mathrm{C}$ for $5 \mathrm{~h}$. The absence of free ions was determined for $\mathrm{Ca}^{2+}$ and $\mathrm{Ba}^{2+}$ ions by titration with a sulfate and for $\mathrm{Al}^{3+}$ ions by reaction with $\mathrm{NaOH}$. Prior to in-situ FTIR studies all the samples were heated in the reaction cell under vacuum to $120{ }^{\circ} \mathrm{C}$ with a temperature ramp of $5^{\circ} \mathrm{C} \min ^{-1}$, which was maintained for $2 \mathrm{~h}$, followed by cooling to the room temperature and degassing under vacuum for $0.5 \mathrm{~h}$. In addition, the acidic ZSM-5, $\mathrm{H}^{+}$-ZSM- 5 has been prepared by the in-situ calcination of $\mathrm{NH}_{4}{ }^{+}$-ZSM- 5 at $500{ }^{\circ} \mathrm{C}$ for $3 \mathrm{~h}$ under vacuum.[40] $\mathrm{H}^{+}$-ZSM-5 prepared by ion-exchange and in-situ calcination of $\mathrm{NH}_{4}{ }^{+}$ZSM-5 exhibit the identical acid sites as shown in Section 3.

\subsection{Characterization}

XRD patterns were recorded on Rigaku Domex powder diffractometer using a continuous scan of $\mathrm{Cu} \mathrm{K}_{\alpha}$ radiation (operational parameters of $4 \mathrm{kV}$ and $22.5 \mathrm{~mA}$ ) equipped with a scintillation type detector which registered Bragg's angles (20) between 5 and $50^{\circ}$.

${ }^{27} \mathrm{Al}$ MAS NMR spectra were recorded at room temperature at $104.3 \mathrm{MHz}$ on a Varian-400 spectrometer equipped with a magic angle spin probe at a spin rate of $5 \mathrm{kHz}$. $\mathrm{AlCl}_{3} \cdot 6 \mathrm{H}_{2} \mathrm{O}$ was used as a reference.

Metal ion $\left(\mathrm{Al}^{3+} / \mathrm{Ca}^{2+} / \mathrm{Ba}^{2+}\right)$ content was measured using inductively couple plasma techniques with a Varian Vista MPX ICP-OES combustion analyzer. Metal ion standards in the range of 2-50 ppm used for instrument calibration were prepared from a $1000 \mathrm{mg}$ 
$\mathrm{L}^{-1}$ (1000 ppm) ICP standard solution (Sigma Aldrich) for each of the metal ions. $\mathrm{M}^{\mathrm{n}+}$ ZSM-5 zeolites were dissolved in 35\% hydrofluoric acid and diluted with deionized water.

\subsection{In-situ FTIR spectroscopy}

In-situ FTIR spectra were recorded with a Nicolet 6700 (Thermo Scientific) infrared spectrometer equipped with a liquid nitrogen cooled mercury cadmium telluride (MCT) detector. Each spectrum was obtained by averaging 128 scans at $2 \mathrm{~cm}^{-1}$ resolution. The samples were mounted in a custom fabricated IR cell which was specifically designed to study highly scattering powder samples in a transmission mode. The IR cell and the preparation of the $\mathrm{M}^{\mathrm{n}+}-\mathrm{ZSM}-5\left(\mathrm{M}^{\mathrm{n}+}=\mathrm{H}^{+}, \mathrm{NH}_{4}^{+}, \mathrm{Al}^{3+}, \mathrm{Ca}^{2+}\right.$, and $\left.\mathrm{Ba}^{2+}\right)$ samples, which are supported on a highly transmissive tungsten mesh $\left(\sim 2 \mathrm{~cm}^{2}\right.$ area $)$, have been described previously.[41-43] In brief, $\mathrm{M}^{\mathrm{n}+}-\mathrm{ZSM}-5$ powders were pressed onto a tungsten grid. The sample was then mounted inside the IR cell which is connected to a turbo pumped gas manifold with a base pressure of $\sim 5 \times 10^{-7}$ Torr. The cell is sealed with $\mathrm{CaF}_{2}$ windows, which can be used for IR transmission studies down to $\sim 1000 \mathrm{~cm}^{-1}$. The sample can be resistively heated to a set temperature, which is measured by a K-type Chromel-Alumel thermocouple attached to center of the grid. After in-situ pretreatment, the background spectra were recorded. Pyridine (Sigma-Aldrich, >99.9\%) was chemisorbed at $110{ }^{\circ} \mathrm{C}$ by admitting the vapor to the cell with the pressure monitored with a capacitance manometer. IR spectra of adsorbed pyridine were recorded after exposure to vacuum at 110,150 and $250{ }^{\circ} \mathrm{C}$, respectively. 


\section{Results and Discussion}

\subsection{Structural properties of the ion-exchanged $\mathrm{M}^{\mathrm{n}+}-\mathrm{ZSM}-5$ zeolites}

The X-ray diffraction data for the series of $\mathrm{M}^{\mathrm{n}+}-\mathrm{ZSM}-5$ zeolites, displayed in Fig. 1, show that all the $\mathrm{M}^{\mathrm{nt}}-\mathrm{ZSM}-5$ zeolites exhibit virtually identical XRD patterns. These patterns are ascribed to the pentasyl type framework structure characteristic of ZSM5.[32, 44] The diffraction patterns confirm that the crystalline structure of ZSM-5 remains the same after the chemical and thermal treatment used in the ion-exchange process. There is no evidence for the presence of a new phase implying that there is no observable formation of metal oxides and no observable incorporation of the loading ions into the ZSM-5 framework. The ${ }^{27}$ Al MAS NMR spectra of $\mathrm{M}^{\mathrm{n}+}-\mathrm{ZSM}-5$ are shown in Fig. 2. All the $\mathrm{M}^{\mathrm{n}+}-\mathrm{ZSM}-5$ samples display a resonance at $\delta \approx 54 \mathrm{ppm}$, which is ascribed to framework tetrahedral $\mathrm{Al}, \mathrm{Al}_{\mathrm{Td}}[9,12,17]$ The resonance at $\delta \approx 0 \mathrm{ppm}$ corresponds to octahedral extra-framework aluminum, $\mathrm{Al}_{\mathrm{Td}-\mathrm{Oh}}$, which has been observed in $\mathrm{Al}^{3+}$-ZSM-5 and in $\mathrm{H}^{+}$-ZSM-5. In the case of $\mathrm{Al}^{3+}-\mathrm{ZSM}-5$, the $\mathrm{Al}^{3+}$ ions loaded on the ZSM-5 coordinate to water ligands in a reversible process resulting in octahedral coordination, which is observed as a resonance around $0 \mathrm{ppm}$. This resonance has been reported to be associated with $\mathrm{H}^{+}$counter ions that can coordinate to water ligands.[45, 46] However, the framework aluminum in $\mathrm{H}^{+}$-ZSM-5 is tetrahedrally coordinated. Based on our data, the ratio of $\mathrm{Al}_{\mathrm{Td}-\mathrm{Oh}}$ to total aluminums in $\mathrm{Al}^{3+}-\mathrm{ZSM}-5$ and $\mathrm{H}^{+}-\mathrm{ZSM}-5$ is $\sim 8$ and $15 \%$, respectively.

In-situ FTIR spectra provide additional information about the structure of the $\mathrm{M}^{\mathrm{n}+}$-ZSM-5 zeolites. Prior experimental and theoretical results clearly indicate there are two types of local structures for $\mathrm{NH}_{4}{ }^{+}$-ZSM-5 --unperturbed and hydrogen-bonded. The latter includes monodentate-, bidentate-, and tridentate- $\mathrm{NH}_{4}{ }^{+}$-ZSM-5.[47] Scheme 1 displays the representative structures of $\mathrm{NH}_{4}{ }^{+}-\mathrm{ZSM}-5$. It has been demonstrated that hydrogen-bonding interactions of the ammonium ion with the charged atoms in the channels play a critical role in stabilizing these ionic structures.[48] Therefore, the hydrogen-bonded structures, such as monodentate-, bidentate-, and tridentate- $\mathrm{NH}_{4}{ }^{+}$ZSM-5 are expected to be the major species rather than the unperturbed ammonium form.[48] This is confirmed by the IR spectrum of $\mathrm{NH}_{4}{ }^{+} \mathrm{ZSM}-5$, which is shown in Fig. 
3(a). The broad absorption bands from 2400 to $3300 \mathrm{~cm}^{-1}$ have been attributed to the $\mathrm{N}-\mathrm{H}$ stretch of the hydrogen-bonded ammonium ion while the sharp band at $3375 \mathrm{~cm}^{-1}$ is attributed to the $\mathrm{N}-\mathrm{H}$ stretch of the unperturbed ammonium ion.[30] The absorption bands around 1450 and $1484 \mathrm{~cm}^{-1}$ are attributed to N-H bending vibration modes of the $\mathrm{NH}_{4}{ }^{+}$moieties with different bonding interactions.[24] The IR bands around 1875 and $2000 \mathrm{~cm}^{-1}$ are assigned to combination bands or overtones of the Si-O stretch in the framework of ZSM-5.[49] The O-H bending mode at $1640 \mathrm{~cm}^{-1}$ is observed for ZSM-5 pretreated at $120^{\circ} \mathrm{C}$ for $2 \mathrm{~h}$ under vacuum indicating that some water is still present even after heating at $120^{\circ} \mathrm{C}$ under vacuum for 2 h. [24] The absorption bands from 3400-3800 $\mathrm{cm}^{-1}$ originate from the various types of O-H stretches.[2, 44, 50] The broad band around $3500 \mathrm{~cm}^{-1}$ is attributed to hydrogen-bonded hydroxyls, including those in water. The absorption band around $3610 \mathrm{~cm}^{-1}$ is ascribed to the Brønsted acid OH groups bridging a $\mathrm{Si}$ and an $\mathrm{Al}$ in the zeolite framework [ $\mathrm{Si}(\mathrm{OH}) \mathrm{Al}]$. The absorption bands at 3685 and $3737 \mathrm{~cm}^{-1}$ are assigned to unperturbed $\mathrm{O}-\mathrm{H}$ stretches of bridging and silanol hydroxyls.[2, $44,50,51]$

After ion-exchange the corresponding cations are substituted for ammonium ions. ICP data show that approximately $1.5 \times 10^{-4} \mathrm{~mol} \mathrm{~g}^{-1} \mathrm{Al}^{3+}$ ions, $2.8 \times 10^{-4} \mathrm{~mol} \mathrm{~g}^{-1} \mathrm{Ca}^{2+}$ ions, and $1.6 \times 10^{-4} \mathrm{~mol} \mathrm{~g}^{-1} \mathrm{Ba}^{2+}$ ions have been exchanged into the ZSM-5. The exchange level of $\mathrm{H}^{+}$with $\mathrm{NH}_{4}{ }^{+}$ions is determined by a comparison of the intensity of the IR absorption band around $1450 \mathrm{~cm}^{-1}$, which is assigned to the bending mode of the bound ions, with the assumption that extinction coefficients are identical in all $\mathrm{M}^{\mathrm{n}+}-\mathrm{ZSM}-5$. The procedure is: (a), integrate the absorption band around $1450 \mathrm{~cm}^{-1}$ for each $\mathrm{M}^{\mathrm{nt}}-\mathrm{ZSM}-5$; (b) calculate the change of the integral of the absorption band around $1450 \mathrm{~cm}^{-1}$ of $\mathrm{M}^{\mathrm{n}+}$ ZSM-5 relative to the same band for $\mathrm{NH}_{4}{ }^{+}-\mathrm{ZSM}-5$; (c) divide the change of the integral of the absorption band by the sample weight; (d) estimate the degree of exchange of $\mathrm{H}^{+}$ ions by using the measured concentration of the exchanged cation in a given ZSM-5. About $5.5 \times 10^{-4} \mathrm{~mol} \mathrm{~g}^{-1} \mathrm{H}^{+}$ions are estimated to be exchanged. As shown in Fig. 3(b)3(d), ion-exchange between $\mathrm{NH}_{4}{ }^{+}$and the cations is further confirmed by the complete disappearance of the absorption band of the unperturbed ammonium ions at $3375 \mathrm{~cm}^{-1}$. In addition, the absorption band due to the ammonia bending mode around $1450 \mathrm{~cm}^{-1}$ and the absorption band due to hydrogen-bonded ammonium ions in the $2400-3300 \mathrm{~cm}^{-1}$ 
region become weaker after ion-exchange. However, the change in the broad absorption in the 2400-3300 $\mathrm{cm}^{-1}$ region varies with different cations. Compared to $\mathrm{NH}_{4}{ }^{+}-\mathrm{ZSM}-5$, the intensities of the absorption bands in the $2400-3300 \mathrm{~cm}^{-1}$ region decrease significantly after ion-exchange with $\mathrm{H}^{+}, \mathrm{Al}^{3+}$, and $\mathrm{Ca}^{2+}$ ions while the intensity of this absorption band in $\mathrm{Ba}^{2+}-\mathrm{ZSM}-5$ is still relatively high. Combined with data on the ion content, as determined by ICP, it is concluded that the ion-exchange for $\mathrm{H}^{+}, \mathrm{Al}^{3+}$, and $\mathrm{Ca}^{2+}$ ions is efficient, but it is less efficient for $\mathrm{Ba}^{2+}$ ions. It is worthwhile to note that the ion-exchange process does not destabilize the ZSM-5 framework. ZSM-5 with high Si/Al ratios is basic and is stabilized by Lewis acidic cations. Thus, it is not surprising that the ZSM-5 we use, with a Si/Al ratio of 80/1, is stabilized under acidic conditions. [33, 34, 52] [33, 34, 51] Correspondingly, ZSM with a low $\mathrm{Si} / \mathrm{Al}$ ratio is expected to be stabilized under basic condition. In the present study, as verified by the identical XRD patterns for $\mathrm{NH}_{4}{ }^{+}-\mathrm{ZSM}-5, \mathrm{Ca}^{2+}-\mathrm{ZSM}-5$ and $\mathrm{Ba}^{2+}-\mathrm{ZSM}-5, \mathrm{ZSM}-5$ is still stable after ion-exchange with basic $\mathrm{Ca}^{2+}$ and $\mathrm{Ba}^{2+}$ ions. One reasonable explanation is that the $\mathrm{Ca}^{2+}$ and $\mathrm{Ba}^{2+}$ ions occupy the same position as occupied by the $\mathrm{NH}_{4}{ }^{+}$ions and do not incorporate into the crystal lattice of ZSM-5. Thus they have a negligible effect on the stability of the structure of ZSM-5.

We now discuss the absorption band around $3610 \mathrm{~cm}^{-1}$ that is assigned to the $\mathrm{O}-\mathrm{H}$ stretch of Brønsted acid hydroxyls. As shown in Fig. 3, it is obvious that this absorption band disappeared after ion-exchanged with $\mathrm{Ca}^{2+}$ and $\mathrm{Ba}^{2+}$ ions whereas this absorption is still present at a relatively high intensity after ion-exchange with $\mathrm{H}^{+}$and $\mathrm{Al}^{3+}$. The disappearance of this absorption is due to the reaction of Brønsted acid hydroxyls with $\mathrm{Ca}^{2+}$ and $\mathrm{Ba}^{2+}$ ions during the ion-exchange process.[27, 53] Additionally, the absorption bands of silanol hydroxyls at 3685 and $3737 \mathrm{~cm}^{-1}$ decreased slightly implying that silanol hydroxyls participate in the reactions of $\mathrm{Ca}^{2+}$ and $\mathrm{Ba}^{2+}$ ions with Brønsted acid hydroxyls. The interaction between the metal cations and ZSM-5 is shown schematically in Scheme 2. We note that the diagram in Scheme 2 should not be viewed as an attempt to present a unique mechanism for the structure of the metal loaded ZSM-5. We simply present a plausible mechanism for the processes under consideration. 


\subsection{Acid sites in $\mathbf{M}^{\mathrm{n}+}$-ZSM-5 zeolites}

\subsubsection{Type and number of acid sites in the $\mathbf{M}^{\mathrm{n}+}-\mathrm{ZSM}-5$ zeolites}

Studies of pyridine adsorption and desorption on the $\mathrm{M}^{\mathrm{n}+}-\mathrm{ZSM}-5$ zeolites were performed using in-situ FTIR spectroscopy with the goal of: (1) determine the types of acid sites; (2) quantify the number of acid sites; (3) estimate the strength of the acid sites.

Fig. 4 shows spectra of pyridine absorbed on $\mathrm{M}^{\mathrm{n}+}-\mathrm{ZSM}-5$ zeolites taken at $110{ }^{\circ} \mathrm{C}$ in the $1700-1400 \mathrm{~cm}^{-1}$ region. The spectra in this region probe the vibrational modes of pyridine adsorbed on the $\mathrm{M}^{\mathrm{n}+}$-ZSM-5 surfaces (shown in Table 1). Heating to $110{ }^{\circ} \mathrm{C}$ prior to pyridine adsorption significantly decreases the influence of adsorbed water and effectively reduces the amount of physisorbed pyridine. All the $\mathrm{M}^{\mathrm{n}+}-\mathrm{ZSM}-5$ zeolites show IR bands due to hydrogen-bonded pyridine (1447 and $1599 \mathrm{~cm}^{-1}$ ) adsorbed on Lewis acid sites (1455 and $1623 \mathrm{~cm}^{-1}$ ), pyridine adsorbed on Brønsted acid sites (1547 and $1640 \mathrm{~cm}^{-1}$ ), and a band at $1490 \mathrm{~cm}^{-1}$ associated with an interaction of pyridine with both Lewis and Brønsted acid sites.[12, 27, 30, 50, 54] As shown in Fig. 5, H+ZSM-5 prepared by calcinations of $\mathrm{NH}_{4}{ }^{+}-\mathrm{ZSM}-5$ and ion exchange shows the identical spectrum for adsorbed pyridine as seen for $\mathrm{H}^{+}-\mathrm{ZSM}-5$ prepared by ion exchange which suggests that these two methods for preparation of $\mathrm{H}^{+}-\mathrm{ZSM}-5$ lead to very similar materials. The Lewis acid sites originate mainly from the framework aluminum species, $A_{\text {Td. }}$ In addition, extra-framework $\mathrm{Al}^{3+}$ ions present on $\mathrm{Al}^{3+}-\mathrm{ZSM}-5$ also act as Lewis acid sites. The Brønsted acid sites mainly originate from the hydroxyls bridging between $\mathrm{Si}$ and $\mathrm{Al}$ as shown in Scheme 1.[25, 32]

In-situ transmission FTIR spectroscopy can be used to quantify the number of acid sites based on the absorption coefficients for these sites reported in the literature.

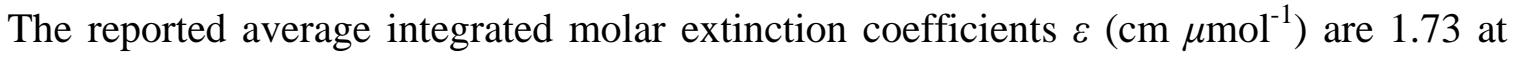
$1445 \mathrm{~cm}^{-1}$ (Lewis acid sites), 1.23 at $1547 \mathrm{~cm}^{-1}$ (Brønsted acid sites) and 1.46 at $1490 \mathrm{~cm}^{-}$

${ }^{1}$ (associated with both Lewis with Brønsted acid sites), respectively.[30, 31] The approximate number of acid sites can therefore be determined based on the Lambert-Beer equation 


$$
C_{W}=\frac{A \times S}{W \times \varepsilon}
$$

Where $C_{W}$, $\left(\mu \mathrm{mol} \mathrm{g}{ }^{-1}\right), A$ (is the length of the $x$ axis for the absorption band in $\mathrm{cm}^{-1}$ ), $W$ $(\mathrm{g})$, and $S\left(\mathrm{~cm}^{2}\right)$ denotes number of acid sites, IR absorption intensity, sample weight, and sample area, respectively. As is shown in Fig. 6 (a), when the $\mathrm{NH}_{4}{ }^{+}$ions in ZSM-5 are replaced by the acidic $\mathrm{H}^{+}$ions, the number of the acid sites increases from 230 to 320 $\mu \mathrm{mol} \mathrm{g} \mathrm{g}^{-1}$. Correspondingly, the number of acid sites decreases from 230 to $90 \mu \mathrm{mol} \mathrm{g} \mathrm{g}^{-1}$ as a result of incorporation of basic $\mathrm{Ba}^{2+}$ ions. The number of acid sites on $\mathrm{Al}^{3+}-\mathrm{ZSM}-5$ and $\mathrm{Ca}^{2+}$-ZSM-5 has been determined as 280 and $160 \mu \mathrm{mol} \mathrm{g}^{-1}$, respectively. Thus, the trend in the number of acid sites for $\mathrm{M}^{\mathrm{n}+}-\mathrm{ZSM}-5$ is: $\mathrm{H}^{+}-\mathrm{ZSM}-5>\mathrm{Al}^{3+}-\mathrm{ZSM}-5>\mathrm{NH}_{4}{ }^{+}-\mathrm{ZSM}-5$ $>\mathrm{Ca}^{2+}-\mathrm{ZSM}-5>\mathrm{Ba}^{2+}-\mathrm{ZSM}-5$. Interestingly, this ordering is consistent with the acidity of the ions $\mathrm{H}^{+}>\mathrm{Al}^{3+}>\mathrm{NH}_{4}{ }^{+}>\mathrm{Ca}^{2+}>\mathrm{Ba}^{2+}$. The reasons for this ordering will be discussed in more detail in Section 3.3.

In addition, as shown in Fig. 6(b), the ion-exchange procedure alters the distribution of Lewis and Brønsted acid sites. The ratio of Lewis to Brønsted acid sites increases in the same order as the Lewis acidity for the metal ions: $\mathrm{Al}^{3+}>\mathrm{NH}_{4}{ }^{+}>\mathrm{Ca}^{2+}>$ $\mathrm{Ba}^{2+}$. However, $\mathrm{H}^{+}-Z \mathrm{SM}-5$ is an exception. The influence of the loaded cations on the total Brønsted and Lewis acid sites and ratio of Brønsted to Lewis acid sites will be discussed in detail in Section 3.3.

\subsubsection{Strength of acid sites in the $M^{\mathrm{n}+}-\mathrm{ZSM}-5$ zeolites}

As discussed in the Introduction, the number and type of acid sites are of primary importance in the acid-catalyzed reactions of zeolites. In addition, the strength of acid sites has been shown to influence reaction rates and mechanisms.[55, 56] For instance, the reaction of methanol to other hydrocarbons was studied over two isostructural zeolite catalysts with different acid strengths, H-SAPO-5 and H-SSZ-24. It was found that acid strength can potentially be used to tune the selectivity of zeolite catalyst towards aromatics and alkanes versus alkenes.[56]

The strength of acid sites in zeolite type catalysts has been subject to both theoretical and experimental investigations.[55, 57-59] Among the methods proposed so 
far, temperature programmed desorption (TPD) is probably most popular. Niwa et al employed IRMS-TPD with ammonia as a probe molecule to estimate the strength of Brønsted acid site in zeolite type catalysts.[60-62] Here, we adopted the IR-TPD method with pyridine as a probe molecule. It has been shown that pyridine molecules are effectively bonded to both Lewis and Brønsted acid sites and therefore the strength of both Lewis and Brønsted acid sites can be determined simultaneously by IR-TPD with pyridine as the probe molecule. Fig. 7 shows the representative spectra of $\mathrm{Al}^{3+}-\mathrm{ZSM}-5$ and $\mathrm{Ca}^{2+}-\mathrm{ZSM}-5$ at different desorption temperatures. The absorption band at $1447 \mathrm{~cm}^{-1}$ decreases significantly when the sample is heated to $150{ }^{\circ} \mathrm{C}$ indicating that the hydrogenbonded pyridine that has an absorption at this frequency is the least strongly bound pyridine moiety. The number of Lewis acid sites increases slightly, which could be due to generation of the more accessible $\mathrm{Al}$ sites as a result of breaking of hydrogen bonds as the temperature is increased to achieve desorption of pyridine. Consistent with this hypothesis, we observed a decrease in the absorption of hydroxyls in the $3500 \mathrm{~cm}^{-1}$ region that correlates with the increase in Lewis acid sites. It has been reported that surface Lewis acid sites are hydrogen-bonded to the adjacent hydroxyls on hydroxyl-rich alumina surfaces.[63] Similar to alumina, the $\mathrm{M}^{\mathrm{nt}}-\mathrm{ZSM}-5$ is also rich in surface hydroxyls. Therefore, the Lewis acid sites are probably hydrogen-bonded to the adjacent hydroxyls. Heating the sample to $150{ }^{\circ} \mathrm{C}$ breaks the hydrogen bond between $\mathrm{Al}$ and the hydroxyls and exposes surface $\mathrm{Al}$ as active Lewis acid sites.

The hydrogen bonded pyridine desorbs between 150 and $200{ }^{\circ} \mathrm{C}$. Pyridine adsorbed on both Brønsted and Lewis acid sites is significantly more stable. There are still strong absorption bands due to pyridine on these latter types of sites that are present even after the $\mathrm{Al}^{3+}$-ZSM-5 and Ca ${ }^{2+}$-ZSM-5 zeolites are heated to $250{ }^{\circ} \mathrm{C}$. In addition, as shown in Fig. 7, as the temperature increases, more pyridine remains bonded to Brønsted acid sites than to Lewis acid sites. This result implies that the Brønsted acid sites form stronger bonds to pyridine than do the Lewis acid sites and thus the Brønsted acid sites are stronger acids. It is worth noting that the respective strength of both Brønsted and Lewis acid sites is virtually identical in all $\mathrm{M}^{\mathrm{n}+}$-ZSM-5 (other spectra not shown). Therefore, the modification of ZSM-5 with different cations only affects the number of 
acid sites and the ratio of Brønsted to Lewis acid sites, but the strength of the acid sites does not change significantly.

\subsection{Influence of cation loading on the number of acid sites in $\mathbf{M}^{\mathrm{n}+}-\mathrm{ZSM}-5$ zeolites}

The acid sites detected in this study are located on the surface of the channels that are accessible to the pyridine.[17] Clearly, acid sites that the pyridine cannot access will not be detected. Therefore, the accessibility of the surface of the channels to the pyridine probe molecule is an important factor in the observed variation of the acid sites among the different zeolites studied. The accessibility of the surface of the channels in $\mathrm{M}^{\mathrm{n}+}$ ZSM-5 is affected by the size of loaded cations. In addition, as discussed in Section 3.1, the loaded cations have different reactivity with Brønsted acid hydroxyls resulting in a variation in the number of acid sites. In the following text, the effect of different cations on the number of acid sites in $\mathrm{M}^{\mathrm{n}+}-\mathrm{ZSM}-5$ will be discussed in terms of the accessibility of the surface of the channels and the possible reactions of the loaded cations with Brønsted acid hydroxyls.

Our reference point for the discussion of the change in the number of acid sites is $\mathrm{NH}_{4}{ }^{+}$-ZSM-5. As shown in Fig. 6(a), the number of Brønsted acid sites in $\mathrm{NH}_{4}{ }^{+}-\mathrm{ZSM}-5$ is $\sim 70 \mu \mathrm{mol} \mathrm{g}$. When $\mathrm{NH}_{4}{ }^{+}$ions on the surface of the channels are substituted by $\mathrm{H}^{+}$ ions, the number of Brønsted acid sites increases to $\sim 130 \mu \mathrm{mol} \mathrm{g}^{-1}$, which is due to the recovery of Brønsted acid sites on the surface of the channels. This is expected since $\mathrm{H}^{+}$ ions now occupy the sites that were occupied by $\mathrm{NH}_{4}{ }^{+}$ions in the $\mathrm{NH}_{4}{ }^{+}-\mathrm{ZSM}-5$ resulting in these sites becoming Brønsted acid sites.[47] The number of Lewis acid sites also increases, from 90 to $110 \mu \mathrm{mol} \mathrm{g}{ }^{-1}$. When the larger radius $\mathrm{NH}_{4}^{+}(\mathrm{r}=1.4 \AA$ ) ions on the surface of the ZSM-5 channels are replaced by a smaller radius $\mathrm{H}^{+}$ions, more aluminum $\mathrm{Al}_{\mathrm{Td}}$ on the surface of channels are exposed, yielding additional accessible Lewis acid sites. Data in Fig. 6(a) demonstrates that substitution of $\mathrm{NH}_{4}{ }^{+}$ions by $\mathrm{Al}^{3+}$ ions does not lead to an increase in the number of the Brønsted acid sites in the framework of ZSM-5. The number of Brønsted acid sites in $\mathrm{Al}^{3+}-\mathrm{ZSM}-5$ and $\mathrm{NH}_{4}{ }^{+}-\mathrm{ZSM}-5$ are both $\sim 80 \mu \mathrm{mol}$ $\mathrm{g}^{-1}$. However, $\mathrm{Al}^{3+}$ ions loaded on the surface of the channels yield more extra-framework Lewis acid sites. Additionally, the smaller size of the $\mathrm{Al}^{3+}$ ions ( $\mathrm{r}=0.7 \AA$ ) compared to the $\mathrm{NH}_{4}{ }^{+}$ions favors exposure of additional accessible Lewis acid sites on the surface of 
the channels. These two factors acting together lead to an increase in the number of accessible Lewis acid sites for the $\mathrm{Al}^{3+}$-ZSM from 100 to $130 \mu \mathrm{mol} \mathrm{g}^{-1}$.

There is a significant change in the number of acid sites that results from loading basic $\mathrm{Ca}^{2+}$ and $\mathrm{Ba}^{2+}$ ions versus the ammonium starting material. As is shown in Fig. 6, there is a loss of both Brønsted and Lewis acid sites in $\mathrm{Ca}^{2+}-\mathrm{ZSM}-5$ and $\mathrm{Ba}^{2+}-\mathrm{ZSM}-5$ compared to $\mathrm{NH}_{4}{ }^{+}-\mathrm{ZSM}-5$. Scheme 2 depicts the fact that the loss of Brønsted acid sites originates mainly from reactions between $\mathrm{Ca}^{2+}$ and $\mathrm{Ba}^{2+}$ ions with Brønsted acid site hydroxyls.[27] This is supported by the disappearance of the absorption band at $3610 \mathrm{~cm}^{-}$ ${ }^{1}$, which is assigned to these sites, upon substitution of $\mathrm{Ca}^{2+}$ and $\mathrm{Ba}^{2+}$ ions for $\mathrm{NH}_{4}^{+}$ions. The decrease in Lewis acid sites arises mainly as a consequence of the steric effect of these ions. In the $\mathrm{Cs}^{+}$-exchanged zeolite $\beta$, it is reported that $\mathrm{Cs}^{+}$ions are located on the surface of the channels of the zeolite $\beta$ and that before $\mathrm{Cs}^{+}$substitution these positions are accessible to pyridine.[39] However, it is logical that the $\mathrm{Cs}^{+}$ions cause a constriction in the diameter of the channels leading to decreased accessibility of these sites to the probe molecules such as pyridine, and thus there is a decrease in both accessible Brønsted and Lewis acid sites measured by pyridine adsorption.[17] Since the $\mathrm{Ba}^{2+}$ and $\mathrm{Cs}^{+}$ions have comparable ionic radii, 1.5 versus $1.7 \AA$,[64] the $\mathrm{Ba}^{2+}$ ions on the surface of the channel are also expected to lead to a constriction of the channels in $\mathrm{Ba}^{2+}-\mathrm{ZSM}-5$. Alternatively, the accessibility of the surface of the channels to probe molecules can be described by the effective radius of the open portion of the channel (micropore).[35] The exchanged cations such as $\mathrm{Ca}^{2+}$ and $\mathrm{Ba}^{2+}$ narrow the effective radius of the micropores by sticking out from the channels of ZSM-5 leading to a significant decrease in the effective channel radius and thus the accessibility of the channels to the pyridine probe molecule. However, another factor could contribute to the change in the number of accessible sites for $\mathrm{Ba}^{2+}$ and $\mathrm{Ca}^{2+}$ loaded zeolites. When the basic $\mathrm{Ba}^{2+}$ and $\mathrm{Ca}^{2+}$ ions react with Brønsted acid hydroxyls, we believe it is plausible that a weakly bonded framework is formed in the channel leading to a larger effective ionic radius which results in greater steric hindrance and therefore makes the surface of the channels even less accessible to probe molecules. This effect would contribute to the observed decrease in the number of accessible Lewis acid sites. The significant decrease in the number of acid sites is verified by the data in Fig. 6(a), where the number of both Brønsted and Lewis acid sites decreases from 70 and 
$100 \mu \mathrm{mol} \mathrm{g}{ }^{-1}$ to 30 and $40 \mu \mathrm{mol} \mathrm{g}^{-1}$ respectively. The steric effect of $\mathrm{Ca}^{2+}$ ions is not as large as for $\mathrm{Ba}^{2+}$ ions, consistent with its smaller radius of $1.1 \AA$. 


\subsection{Implications}

Zeolites have been widely used as acid catalysts for hydrocarbons for over 50 years. $[2,25]$ Due to the importance of their acid sites in many catalytic reactions, strategies have been developed for the direct synthesis of zeolite frameworks with specific number of Brønsted and Lewis acid sites. However, most of these direct synthetic methods are relatively complex. The present work demonstrates that loading acidic or basic cations through ion-exchange not only changes the number of total acid sites on zeolites but also alters the ratio of Brønsted to Lewis acid sites. In the "acid" catalyzed reactions, controlling the ratio of Brønsted to Lewis acid sites can be of great importance for a given reaction in order to obtain higher conversion and selectivity. For example, a higher ratio of Brønsted to Lewis acid sites on HY zeolites is desirable for the efficient aqueous phase dehydration of carbohydrates to furfural;[3] a high ratio of Lewis to Brønsted acid sites on zeolite $\mathrm{Y}$ favors the isomerization of glucose to fructose.[10]

We also note that the loaded cations could potentially increase interactions between reactive molecules and the zeolite support enhancing their reactive behavior.[39, 65-72] For example, Kuwahara et al. designed a new class of heterogeneous catalytic systems utilizing this effect: cation $-\pi$ interactions ( $\pi$ from potential reactive molecules) in microporous titanosilicate molecular sieves for cyclohexene epoxidation.[39] Possibly the heavier alkali metal cations $\left(\mathrm{K}^{+}, \mathrm{Rb}^{+}\right.$, and $\left.\mathrm{Cs}^{+}\right)$have an increased interaction with the cyclohexene molecules as a result of a weak cation- $\pi$ interaction, which results in an enhancement of their catalytic activity and selectivity for epoxidation. 


\section{Conclusion}

The acid sites on the surface of $\mathrm{M}^{\mathrm{n}+}-\mathrm{ZSM}-5$ modified by exchange with $\mathrm{H}^{+}, \mathrm{Al}^{3+}, \mathrm{Ca}^{2+}$ and $\mathrm{Ba}^{2+}$ ions have been systematically investigated using X-ray diffraction, ${ }^{27} \mathrm{Al}$ MAS NMR, and in-situ FTIR spectroscopy. The XRD and ${ }^{27}$ Al MAS NMR results demonstrate the stability of the ZSM-5 structure after the ion-exchange procedure. In-situ FTIR spectroscopy, with pyridine as a probe molecule, was used to determine the type, number, and strength of the acid sites. The number of acid sites in $\mathrm{M}^{\mathrm{n}+}-\mathrm{ZSM}-5$ varies in the order $\mathrm{Ba}^{2+}$-ZSM-5 $<\mathrm{Ca}^{2+}-\mathrm{ZSM}-5<\mathrm{NH}_{4}{ }^{+}-\mathrm{ZSM}-5<\mathrm{Al}^{3+}$-ZSM-5 $<\mathrm{H}^{+}$-ZSM-5, which parallels the acidity of the loaded cations: $\mathrm{Ba}^{2+}<\mathrm{Ca}^{2+}<\mathrm{NH}_{4}^{+}<\mathrm{Al}^{3+}<\mathrm{H}^{+}$. Pyridine desorption data demonstrate that the majority of the pyridine remains bound to both Brønsted and Lewis acid sites even after heating to $250{ }^{\circ} \mathrm{C}$ and that the strength of acid sites in all $\mathrm{M}^{\mathrm{n}+}$ ZSM-5 zeolites is virtually identical. The change in the number of acid sites of $\mathrm{M}^{\mathrm{n}+}$ ZSM-5 is discussed in terms of the accessibility of the surface of the channels and the reactivity of the loaded cations with Brønsted acid hydroxyls. Loading small acidic cations, such as $\mathrm{H}^{+}$ions, leads to the recovery of Brønsted acid sites. Additionally, the small ionic radius of $\mathrm{H}^{+}$ions compared to the large ionic radius of $\mathrm{NH}_{4}{ }^{+}$ions make the surface of the channels more accessible and results in an increase in number of both Lewis and Brønsted acid sites. Though loading with $\mathrm{Al}^{3+}$ ions does not lead to recovery of Brønsted acid sites, the loaded $\mathrm{Al}^{3+}$ ions generate more extra-framework $\mathrm{Al}^{3+}$ ions, resulting in an increase in the number of Lewis acid sites in ZSM-5. In addition, the $\mathrm{Al}^{3+}$ ions, with a small ionic radius, make the surface of the channels in ZSM-5 more accessible than the $\mathrm{NH}_{4}{ }^{+}$reference zeolite. The situation is different for Ca ${ }^{2+}-\mathrm{ZSM}-5$ and $\mathrm{Ba}^{2+}-\mathrm{ZSM}-5$. Loading basic $\mathrm{Ca}^{2+}$ and $\mathrm{Ba}^{2+}$ ions significantly reduces the acidity of ZSM5. Basic $\mathrm{Ca}^{2+}$ and $\mathrm{Ba}^{2+}$ ions react with Brønsted acid hydroxyls, leading to the loss of the Brønsted acid sites. These large $\mathrm{Ca}^{2+}$ and $\mathrm{Ba}^{2+}$ ions lead to a constriction of the zeolite channels and make acid sites less accessible to pyridine (and other small molecules). Additionally, we propose that a weakly bonded framework is formed between $\mathrm{Ca}^{2+}$ and $\mathrm{Ba}^{2+}$ ions and surface hydroxyls leading to even larger effective radii for $\mathrm{Ca}^{2+}$ and $\mathrm{Ba}^{2+}$ ions. This decrease in accessibility appears as a loss of acid sites but is really a decrease in the number of Lewis and Brønsted acid sites that are accessible to the pyridine probe molecule. 


\section{Acknowledgment}

This work was supported by the Chemical Sciences, Geosciences, and Biosciences Division, Office of Basic Energy Sciences, Office of Science, U.S. Department of Energy (Award No. DE-FG02-03-ER15457). We thank Yuyuan Lin for assistance in collecting the XRD data. Solid-state NMR spectroscopy and ICP were performed in the IMSERC Facilities at Northwestern University supported by NSF DMR-0521267. Authors appreciate Dr Yuyang Wu at IMSERC for NMR measurement. 


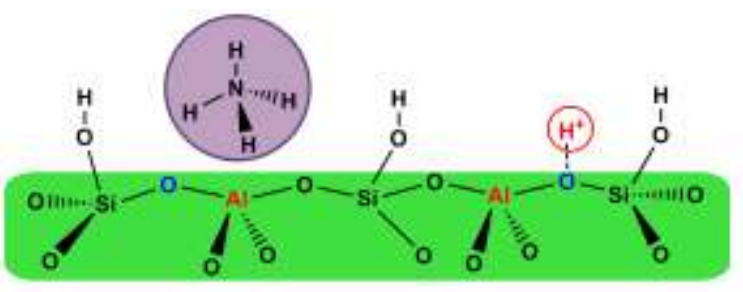

Free $\mathrm{NH}_{4}{ }^{+}-\mathrm{ZSM}-5$

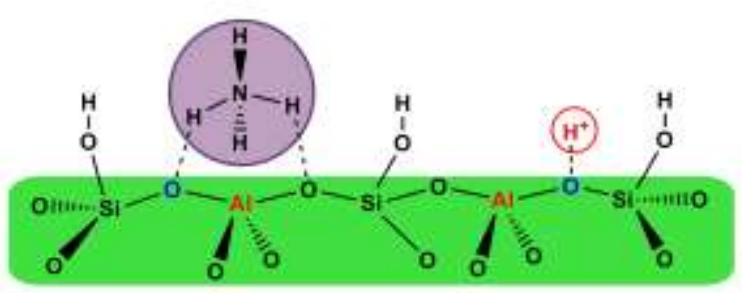

Bidentate $\mathrm{NH}_{4}{ }^{+}$-ZSM-5

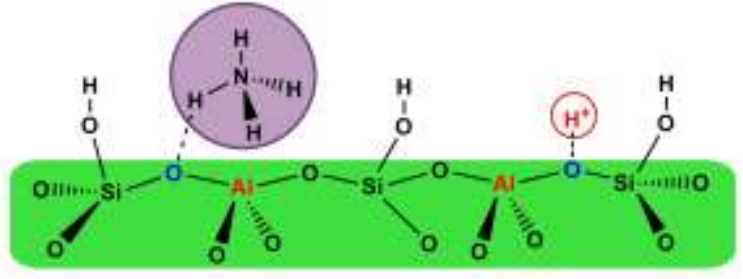

Monodentate $\mathrm{NH}_{4}{ }^{+}-\mathrm{ZSM}-5$

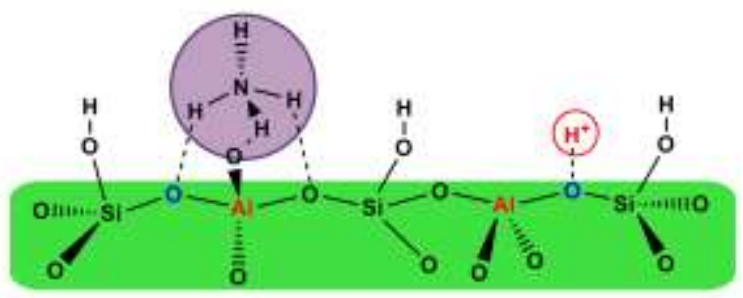

Tridentate $\mathrm{NH}_{4}{ }^{+}$-ZSM-5

Scheme 1. Schematic of Possible Structures of $\mathrm{NH}_{4}{ }^{+}$-ZSM-5 


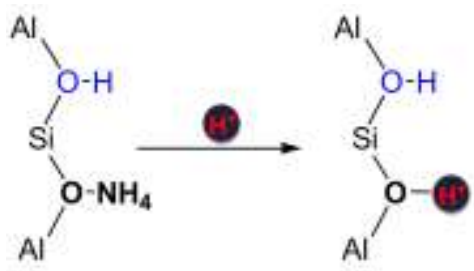

$\mathrm{H}^{+}-\mathrm{ZSM}-5$

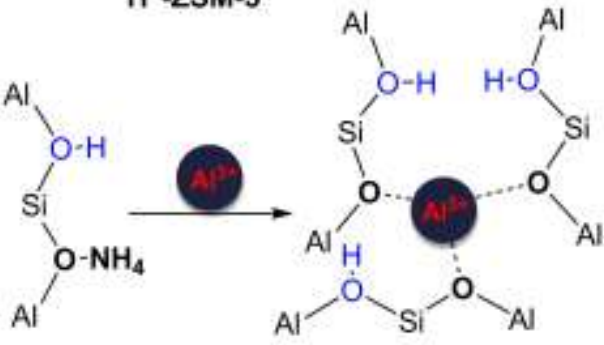

$\mathrm{Al}^{3+}$-ZSM-5

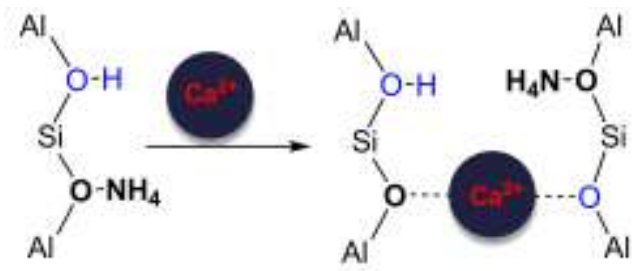

$\mathrm{Ca}^{2+}-\mathrm{ZSM}-5$
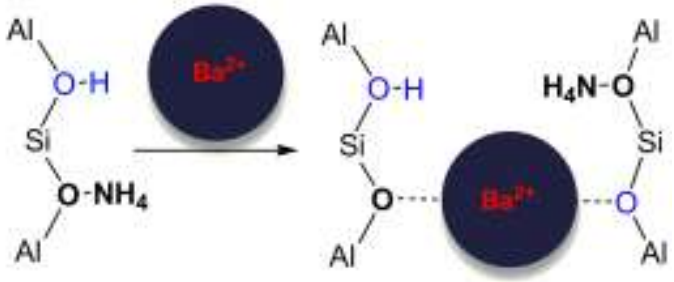

$\mathrm{Ba}^{2+}-\mathrm{ZSM}-5$

Scheme 2. Schematic of Possible Mechanisms for the Formation of $\mathrm{M}^{\mathrm{n}+}-\mathrm{ZSM}-5$ 
Table1. Vibration frequencies of the $\mathrm{CC}$ bond in pyridine bound to different sites in $\mathrm{M}^{\mathrm{n}+}$ ZSM-5

\begin{tabular}{ccc}
\hline Absorption bands/cm & Vibration modes & Linkage of pyridine \\
\hline 1640 & $v_{\mathrm{CC}(\mathrm{N})}$ & Brønsted acid sites \\
1623 & $v_{\mathrm{CC}(\mathrm{N})}$ & Lewis acid sites \\
1599 & $v_{\mathrm{CC}(\mathrm{N})}$ & Hydrogen-bonded \\
1547 & $v_{\mathrm{CC}(\mathrm{N})}$ & Brønsted acid sites \\
1490 & $v_{\mathrm{CC}(\mathrm{N})}$ & Brønsted and Lewis acid sites \\
1455 & $v_{\mathrm{CC}(\mathrm{N})}$ & Lewis acid sites \\
1447 & $v_{\mathrm{CC}(\mathrm{N})}$ & Hydrogen-bonded \\
\hline
\end{tabular}




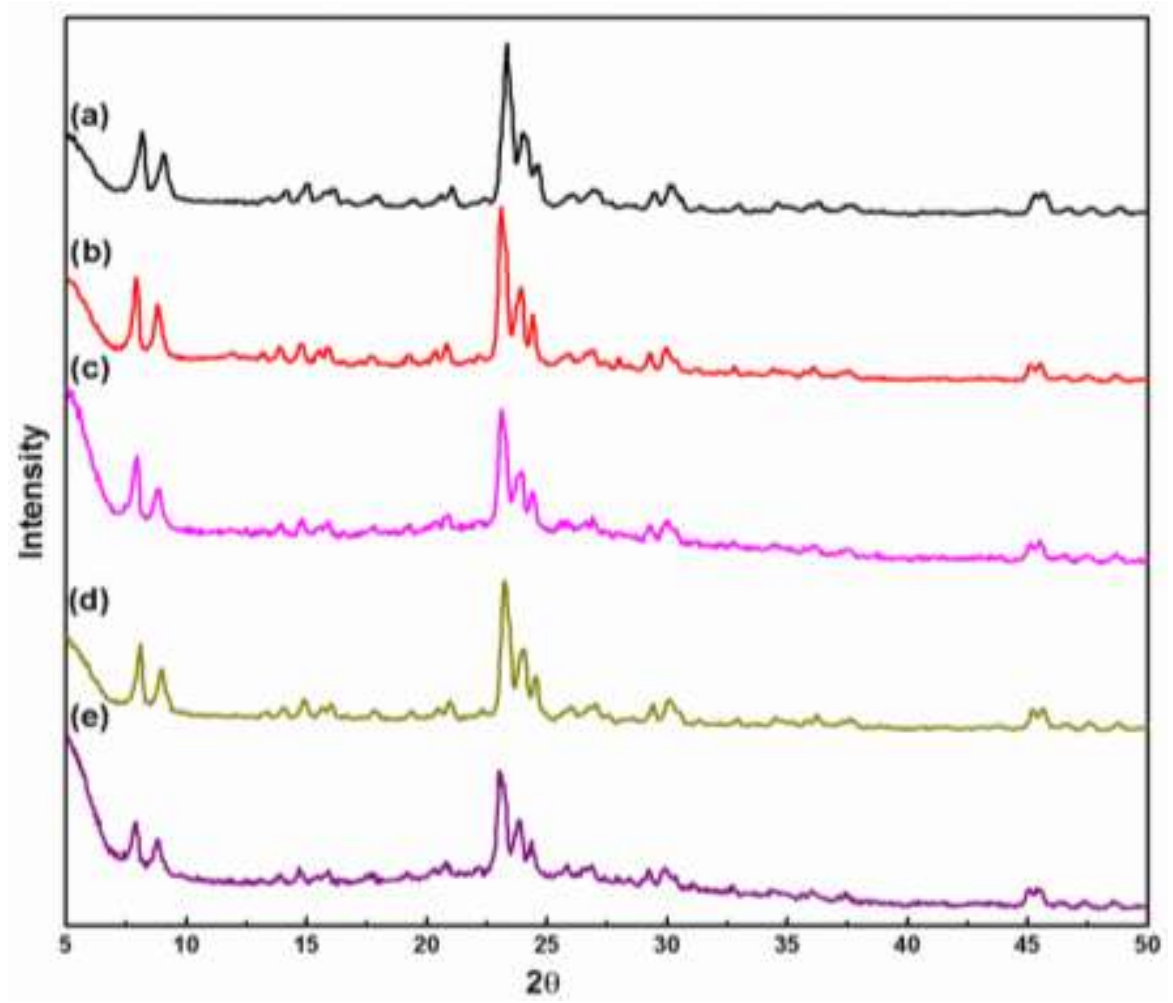

Fig. 1.X-ray diffraction patterns of $\mathrm{M}^{\mathrm{n}+}-\mathrm{ZSM}-5$ : (a) $\mathrm{NH}_{4}{ }^{+}-\mathrm{ZSM}-5$; (b) $\mathrm{Al}^{3+}-\mathrm{ZSM}-5$; (c) $\mathrm{H}^{+}-\mathrm{ZSM}-5$; (d) $\mathrm{Ba}^{2+}$-ZSM-5; (e) $\mathrm{Ca}^{2+}$-ZSM-5. 


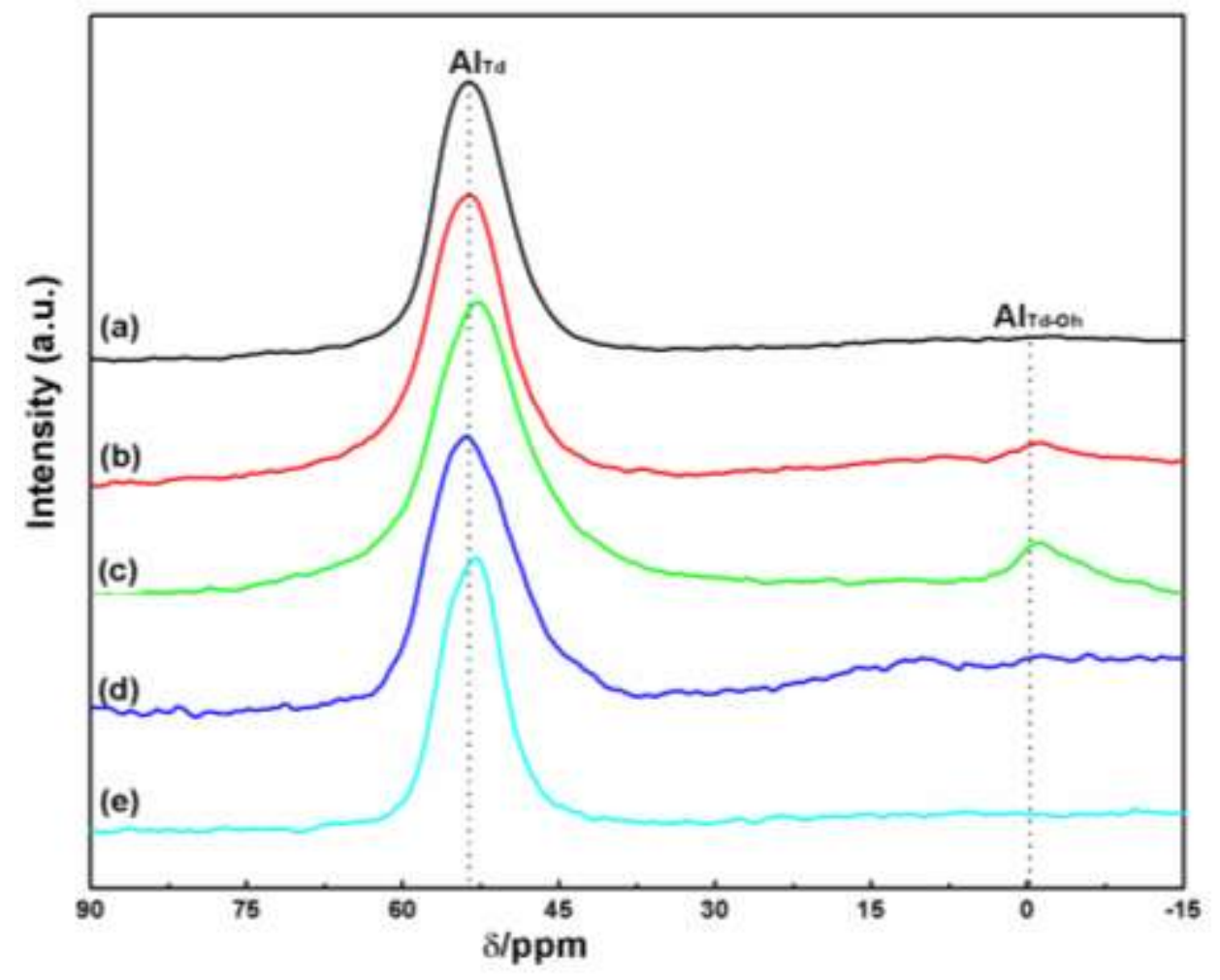

Fig. $2 .{ }^{27} \mathrm{Al}$ MAS NMR spectra of $\mathrm{M}^{\mathrm{n}+}-\mathrm{ZSM}-5$ : (a) $\mathrm{NH}_{4}{ }^{+}-\mathrm{ZSM}-5$; (b) $\mathrm{Al}^{3+}-\mathrm{ZSM}-5$; (c) $\mathrm{H}^{+}$-ZSM-5; (d) Ca ${ }^{2+}-\mathrm{ZSM}-5$; (e) $\mathrm{Ba}^{2+}-\mathrm{ZSM}-5$. 


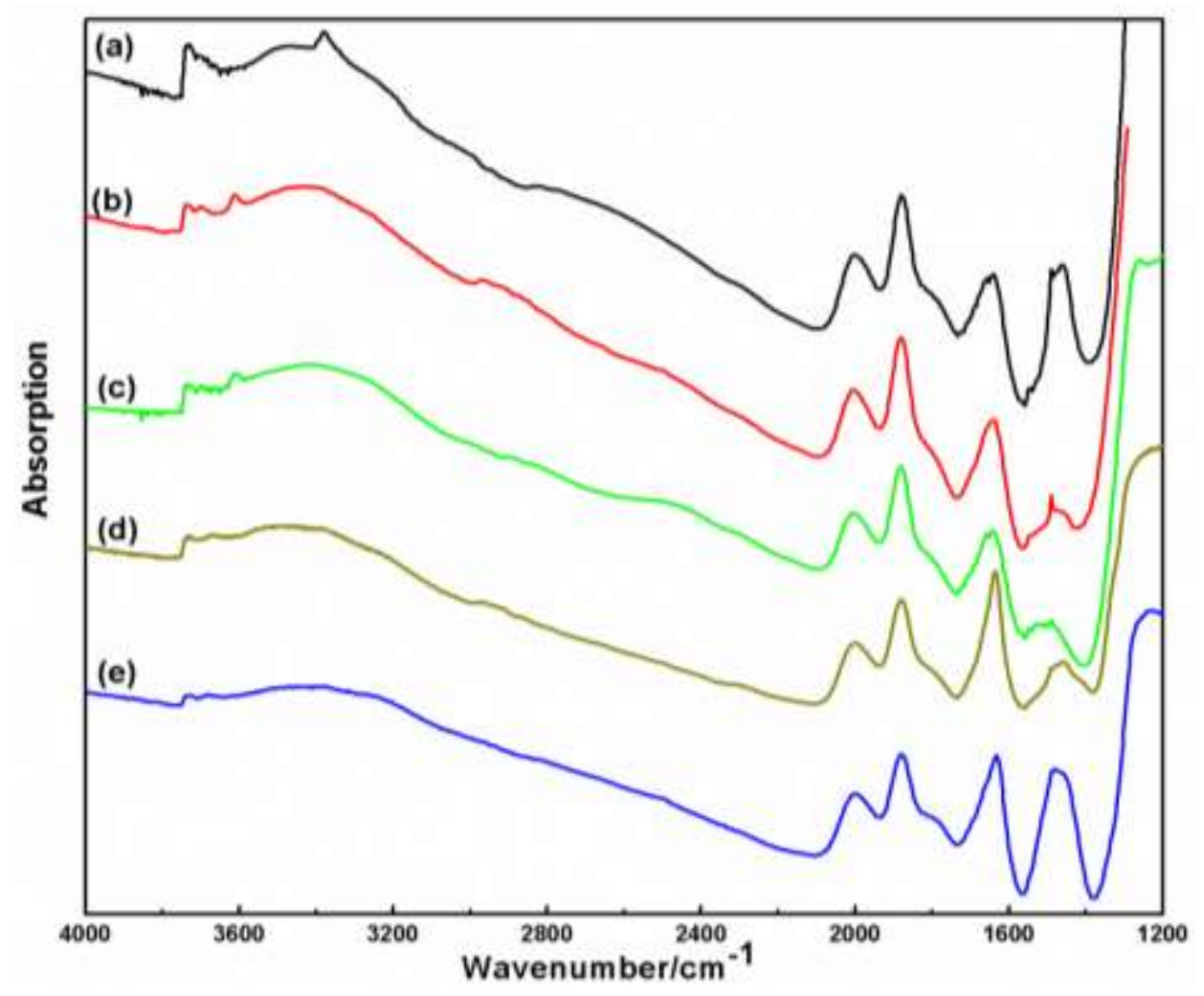

Fig. 3. IR spectra of $\mathrm{M}^{\mathrm{n}+}-\mathrm{ZSM}-5$ : (a) $\mathrm{NH}_{4}{ }^{+}-\mathrm{ZSM}-5$, (b) $\mathrm{Al}^{3+}-\mathrm{ZSM}-5$, (c) $\mathrm{H}^{+}-\mathrm{ZSM}-5$, (d) $\mathrm{Ca}^{2+}$-ZSM-5; (e) $\mathrm{Ba}^{2+}$-ZSM-5. 


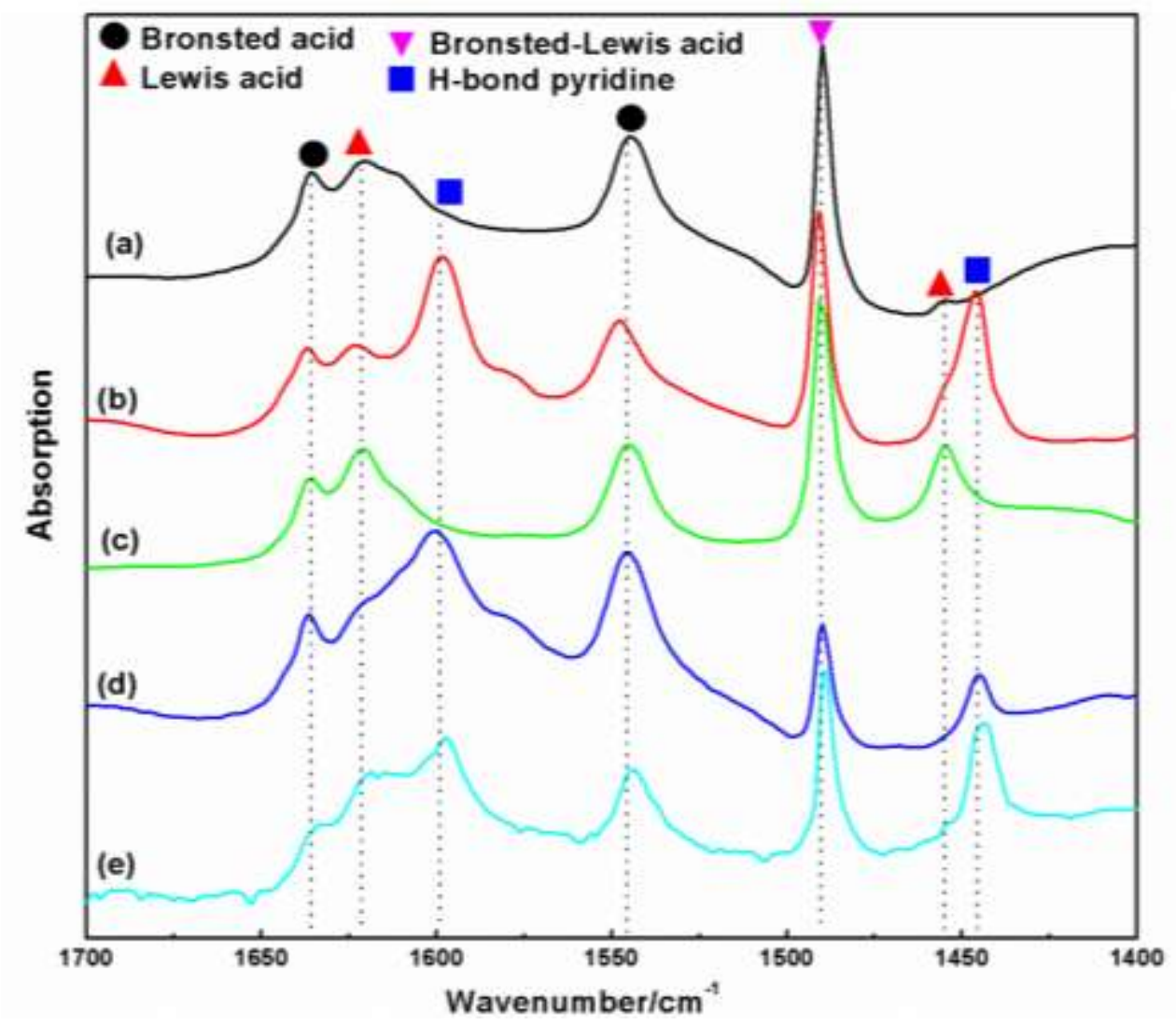

Fig. 4. IR spectra of pyridine adsorbed on $\mathrm{M}^{\mathrm{n}+}-\mathrm{ZSM}-5$ at $110{ }^{\circ} \mathrm{C}$ : (a) $\mathrm{NH}_{4}{ }^{+}-\mathrm{ZSM}-5$; (b) $\mathrm{Al}^{3+}$-ZSM-5; (c) $\mathrm{H}^{+}-\mathrm{ZSM}-5$; (d) $\mathrm{Ca}^{2+}$-ZSM-5; (e) $\mathrm{Ba}^{2+}-\mathrm{ZSM}-5$. 


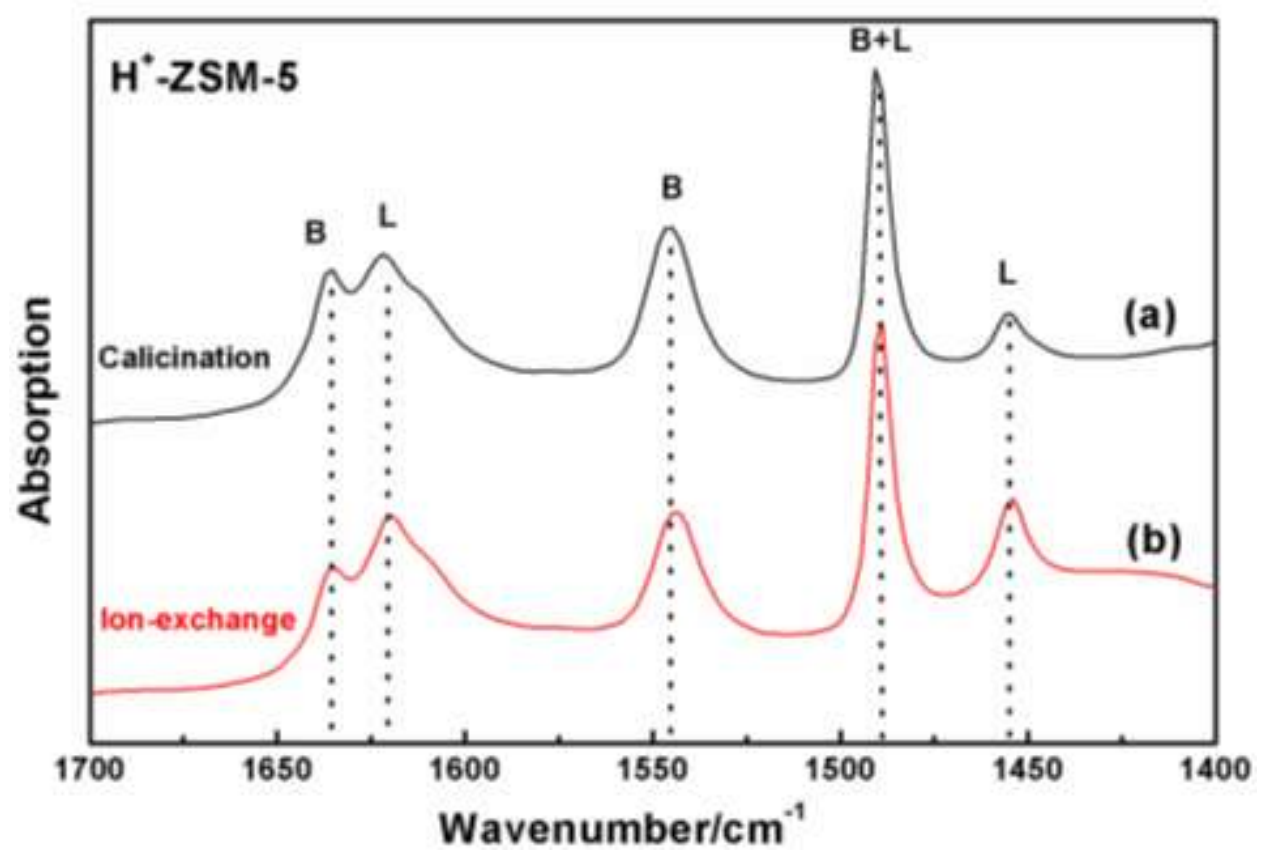

Fig. 5. IR spectra of pyridine adsorbed on $\mathrm{H}^{+}-\mathrm{ZSM}-5$ at $110{ }^{\circ} \mathrm{C}$ : (a) prepared by calcinations of $\mathrm{NH}_{4}{ }^{+}$-ZSM-5; (b) prepared ion-exchange with aqueous nitric acid. 

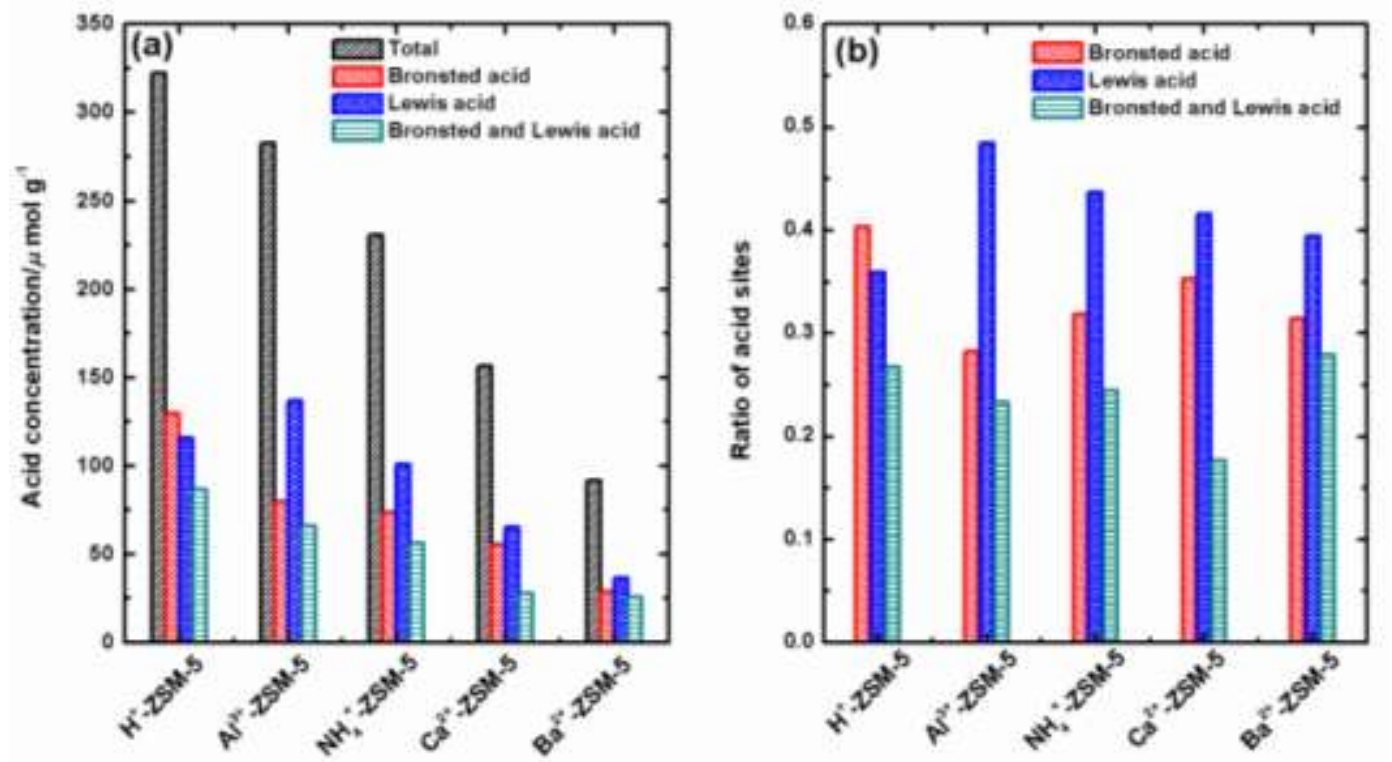

Fig. 6. Comparison of the total number of Lewis and Brønsted acid sites (a), and ratio of a given type of acid site to the total number of acid sites (b) in $\mathrm{M}^{\mathrm{n}+}-\mathrm{ZSM}-5$. 

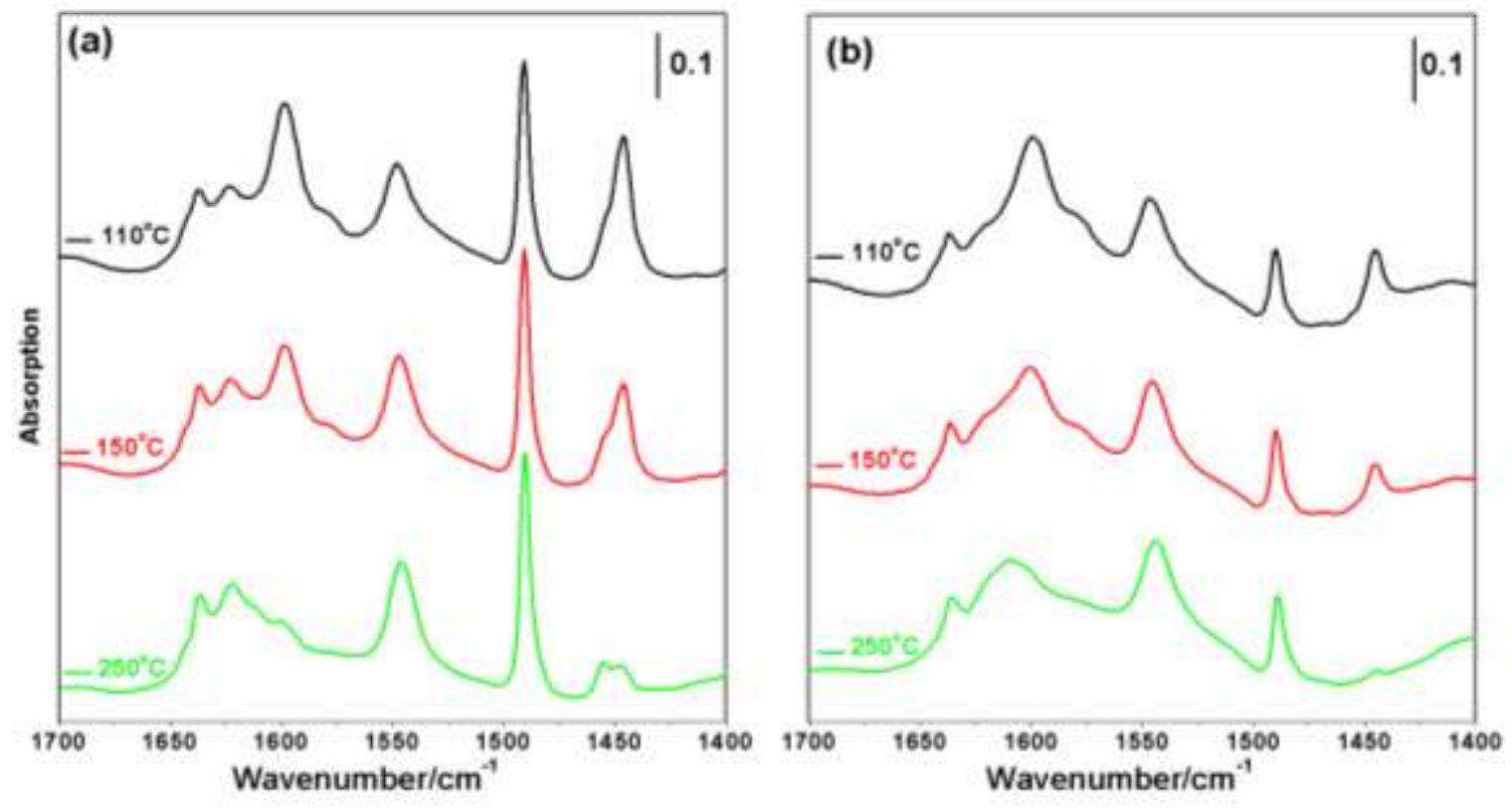

Fig. 7. IR spectra after pyridine desorption from $\mathrm{M}^{\mathrm{n}+}-\mathrm{ZSM}-5$ at different temperatures: (a) $\mathrm{Al}^{3+}-\mathrm{ZSM}-5$; (b) $\mathrm{Ca}^{2+}-\mathrm{ZSM}-5$. 


\section{Reference}

[1] A. Corma, Inorganic solid acids and their use in acid-catalyzed hydrocarbon reactions, Chemical Reviews, 95 (1995) 559-614.

[2] G. Busca, Acid catalysts in industrial hydrocarbon chemistry, Chemical Reviews, 107 (2007) 5366-5410.

[3] R. Weingarten, G.A. Tompsett, W.C. Conner, G.W. Huber, Design of solid acid catalysts for aqueous-phase dehydration of carbohydrates: The role of Lewis and Bronsted acid sites, Journal of Catalysis, 279 (2011) 174-182.

[4] W.O. Haag, D.H. Olson, P.B. Weisz, The active site of acidic aluminosilicate catalysts, Nature, 309 (1984) 589-591.

[5] I.E. Maxwell, W. Stork, Chapter 17 Hydrocarbon processing with zeolites, Stud. Surf. Sci. Catal, 137 (2001) 747.

[6] J.F. Haw, W.G. Song, D.M. Marcus, J.B. Nicholas, The mechanism of methanol to hydrocarbon catalysis, Accounts Chem. Res., 36 (2003) 317-326.

[7] J.F. Haw, J.B. Nicholas, W.G. Song, F. Deng, Z.K. Wang, T. Xu, C.S. Heneghan, Roles for cyclopentenyl cations in the synthesis of hydrocarbons from methanol on zeolite catalyst HZSM-5, Journal of the American Chemical Society, 122 (2000) 47634775.

[8] Y.M. Liu, H.Q. Yang, F. Jin, Y. Zhang, Y.D. Li, Synthesis of pyridine and picolines over Co-modified HZSM-5 catalyst, Chemical Engineering Journal, 136 (2008) 282-287. [9] J.L. Motz, H. Heinichen, W.F. Holderich, Direct hydroxylation of aromatics to their corresponding phenols catalysed by H- Al ZSM-5 zeolite, Journal of Molecular Catalysis a-Chemical, 136 (1998) 175-184.

[10] S. Saravanamurugan, M. Paniagua, J.A. Melero, A. Riisager, Efficient Isomerization of Glucose to Fructose over Zeolites in Consecutive Reactions in Alcohol and Aqueous Media, Journal of the American Chemical Society, 135 (2013) 5246-5249.

[11] N.Y. Chen, W.E. Garwood, F.G. Dwyer, Shape Selective Catalysis in Industrial Applications, M. Dekker Inc., New York, (1989) p. 157.

[12] Y. Li, W.H. Zhang, L. Zhang, Q.H. Yang, Z.B. Wei, Z.C. Feng, C. Li, Direct synthesis of Al-SBA-15 mesoporous materials via hydrolysis-controlled approach, Journal of Physical Chemistry B, 108 (2004) 9739-9744.

[13] B.M.C. Shekara, B.S.J. Prakash, Y.S. Bhat, Dealumination of Zeolite BEA under Microwave Irradiation, Acs Catalysis, 1 (2011) 193-199.

[14] P. Matias, J.M. Lopes, P. Ayrault, S. Laforge, P. Magnoux, M. Guisnet, F.R. Ribeiro, Effect of dealumination by acid treatment of a HMCM-22 zeolite on the acidity and activity of the pore systems, Applied Catalysis a-General, 365 (2009) 207-213. [15] U. Myeong-Heon, M. Kang, The effect of dealumination on the framework stability, acidity, and catalytic performance of SAPO-11 molecular sieves, Journal of Industrial and Engineering Chemistry, 11 (2005) 540-549.

[16] J. Zheng, J.L. Dong, Q.H. Xu, Y. Liu, A.Z. Yan, Comparison between beta-zeolites and l-zeolites supported platinum for n-hexane aromatization, Applied Catalysis aGeneral, 126 (1995) 141-152.

[17] S. Ramirez, J.M. Dominguez, M. Viniegra, L.C. de Menorval, Specific behavior of beta-zeolites upon the modification of the surface acidity by Cs and Li exchange, New Journal of Chemistry, 24 (2000) 99-104. 
[18] A. Coelho, L. Costa, M.M. Marques, I.M. Fonseca, M. Lemos, F. Lemos, The effect of ZSM-5 zeolite acidity on the catalytic degradation of high-density polyethylene using simultaneous DSC/TG analysis, Applied Catalysis a-General, 413 (2012) 183-191.

[19] A. Ates, C. Hardacre, The effect of various treatment conditions on natural zeolites: Ion exchange, acidic, thermal and steam treatments, Journal of Colloid and Interface Science, 372 (2012) 130-140.

[20] Ivanova, II, N. Blom, E.G. Derouane, Controlled-atmosphere C-13 MAS NMR study of the initial stages of propane activation over H-ZSM-5, Elsevier Science Publ B V, Amsterdam, 1995.

[21] A.M. Zheng, S.B. Liu, F. Deng, Chemoselectivity during propene hydrogenation reaction over H-ZSM-5 zeolite: Insights from theoretical calculations, Microporous and Mesoporous Materials, 121 (2009) 158-165.

[22] H. Tsuji, A. Okamura-Yoshida, T. Shishido, H. Hattori, Dynamic behavior of carbonate species on metal oxide surface: Oxygen scrambling between adsorbed carbon dioxide and oxide surface, Langmuir, 19 (2003) 8793-8800.

[23] N. Katada, K. Suzuki, T. Noda, M.B. Park, H.K. Min, S.B. Hong, M. Niwa, Ammonia IRMS-TPD Characterization of Bronsted Acid Sites in Medium-pore Zeolites with Different Framework Topologies, Topics in Catalysis, 53 (2010) 664-671.

[24] K. Suzuki, T. Noda, N. Katada, M. Niwa, IRMS-TPD of ammonia: Direct and individual measurement of Bronsted acidity in zeolites and its relationship with the catalytic cracking activity, Journal of Catalysis, 250 (2007) 151-160.

[25] W.E. Farneth, R.J. Gorte, Methods for characterizing zeolite acidity, Chemical Reviews, 95 (1995) 615-635.

[26] N.B. Muddada, U. Olsbye, T. Fuglerud, S. Vidotto, A. Marsella, S. Bordiga, D. Gianolio, G. Leofanti, C. Lamberti, The role of chlorine and additives on the density and strength of Lewis and Bronsted acidic sites of gamma- $\mathrm{Al}_{2} \mathrm{O}_{3}$ support used in oxychlorination catalysis: A FTIR study, Journal of Catalysis, 284 (2011) 236-246. [27] E.M. El-Malki, R.A. van Santen, W.M.H. Sachtler, Introduction of Zn, Ga, and Fe into HZSM-5 cavities by sublimation: Identification of acid sites, Journal of Physical Chemistry B, 103 (1999) 4611-4622.

[28] S. Bhatia, J. Beltramini, D.D. Do, Temperature programmed analysis and its applications in catalytic systems, catalysis Today, 7 (1990) 309-438.

[29] J. Datka, A.M. Turek, J.M. Jehng, I.E. Wachs, Acidic properties of supported niobium oxide catalysts - an infrared-spectroscopy investigation, Journal of Catalysis, 135 (1992) 186-199.

[30] C.A. Emeis, Determination of integrated molar extinction coefficients for infraredabsorption bands of pyridine adsorbed on solid acid catalysts, Journal of Catalysis, 141 (1993) 347-354.

[31] M. Tamura, K.-i. Shimizu, A. Satsuma, Comprehensive IR study on acid/base properties of metal oxides, Applied Catalysis a-General, 433 (2012) 135-145.

[32] G.L. Woolery, G.H. Kuehl, H.C. Timken, A.W. Chester, J.C. Vartuli, On the nature of framework Bronsted and Lewis acid sites in ZSM-5, Zeolites, 19 (1997) 288-296. [33] A. Chatterjee, F. Mizukami, Location and role of exchangeable cations in zeolite catalysis: a first principle study, Chemical Physics Letters, 385 (2004) 20-24.

[34] B. Bonelli, B. Onida, J.D. Chen, A. Galarneau, F. Di Renzo, F. Fajula, E. Garrone, Spectroscopic characterisation of the strength and stability of the acidic sites of Al-rich 
microporous micelle-templated silicates, Microporous and Mesoporous Materials, 67 (2004) 95-106.

[35] T. Yashima, N. Hara, Infrared study of cation-exchanged mordenites and y faujasites adsorbed with ammonia and pyridine., Journal of Catalysis, 27 (1972) 329-331. [36] M. Niwa, S. Nishikawa, N. Katada, IRMS-TPD of ammonia for characterization of acid site in beta-zeolite, Microporous and Mesoporous Materials, 82 (2005) 105-112. [37] K. Suzuki, G. Sastre, N. Katada, M. Niwa, Ammonia IRMS-TPD measurements and DFT calculation on acidic hydroxyl groups in CHA-type zeolites, Physical Chemistry Chemical Physics, 9 (2007) 5980-5987.

[38] N. Katada, T. Tsubaki, M. Niwa, Measurements of number and strength distribution of Bronsted and Lewis acid sites on sulfated zirconia by ammonia IRMS-TPD method, Applied Catalysis a-General, 340 (2008) 76-86.

[39] Y. Kuwahara, K. Nishizawa, T. Nakajima, T. Kamegawa, K. Mori, H. Yamashita, Enhanced Catalytic Activity on Titanosilicate Molecular Sieves Controlled by Cation-pi Interactions, Journal of the American Chemical Society, 133 (2011) 12462-12465. [40] V.S. Nayak, V.R. Choudhary, Acid strength distribution and catalytic properties of $\mathrm{H}^{+}$-ZSM-5 - effect of deammoniation conditions of $\mathrm{NH}_{4}{ }^{+}$-ZSM-5, Journal of Catalysis, 81 (1983) 26-45.

[41] Y.H. Yeom, B. Wen, W.M.H. Sachtler, E. Weitz, $\mathrm{NO}_{\mathrm{x}}$ reduction from diesel emissions over a nontransition metal zeolite catalyst: A mechanistic study using FTIR spectroscopy, Journal of Physical Chemistry B, 108 (2004) 5386-5404.

[42] P. Basu, T.H. Ballinger, J.T. Yates, Wide temperature-range ir spectroscopy cell for studies of adsorption and desorption on high area solids, Review of Scientific Instruments, 59 (1988) 1321-1327.

[43] W.Q. Wu, K. Bhattacharyya, K. Gray, E. Weitz, Photoinduced Reactions of SurfaceBound Species on Titania Nanotubes and Platinized Titania Nanotubes: An in Situ FTIR Study, Journal of Physical Chemistry C, 117 (2013) 20643-20655.

[44] F. Jin, Y. Li, A FTIR and TPD examination of the distributive properties of acid sites on ZSM-5 zeolite with pyridine as a probe molecule, Catalysis Today, 145 (2009) 101-107.

[45] F. Fajula, Geometry of the active sites in zeolites under working conditions, Stud. Surf. Sci. Catal, 97 (1995) 133-141.

[46] E. Bourgeat-Lami, P. Massiani, F. Direnzo, P. Espiau, F. Fajula, T.D. Courieres, Study of the state of aluminum in zeolite-beta, Applied Catalysis, 72 (1991) 139-152. [47] A. Zecchina, L. Marchese, S. Bordiga, C. Paze, E. Gianotti, Vibrational spectroscopy of $\mathrm{NH}_{4}{ }^{+}$ions in zeolitic materials: An IR study, Journal of Physical Chemistry B, 101 (1997) 10128-10135.

[48] A. Kyrlidis, S.J. Cook, A.K. Chakraborty, A.T. Bell, D.N. Theodorou, Electronicstructure calculations of ammonia adsorption in H-ZSM-5 zeolites, J. Phys. Chem., 99 (1995) 1505-1515.

[49] X.Y. Liu, L.Q. She, S.W. Li, An infrared spectroscopy method for measuring the Bronsted acid of ZSM-5 and the study of surface acidity of modified ZSM-5 zeolite, Acta Physico-Chemica Sinica, 1 (1985) 533-542.

[50] X. Liu, DRIFTS study of surface of gamma-alumina and its dehydroxylation, Journal of Physical Chemistry C, 112 (2008) 5066-5073. 
[51] Y.G. Kolyagin, V.V. Ordomsky, Y.Z. Khimyak, A.I. Rebrov, F. Fajula, Ivanova, II, Initial stages of propane activation over Zn/MFI catalyst studied by in situ NMR and IR spectroscopic techniques, Journal of Catalysis, 238 (2006) 122-133.

[52] H. Matsuura, N. Katada, M. Niwa, Additional acid site on HZSM-5 treated with basic and acidic solutions as detected by temperature-programmed desorption of ammonia, Microporous and Mesoporous Materials, 66 (2003) 283-296.

[53] Y.G. Kolyagin, Ivanova, II, V.V. Ordomsky, A. Gedeon, Y.A. Pirogov, Methane Activation over Zn-Modified MFI Zeolite: NMR Evidence for Zn-Methyl Surface Species Formation, Journal of Physical Chemistry C, 112 (2008) 20065-20069.

[54] E.P. Parry, An infrared study of pyridine adsorbed on acidic solids characterization of surface acidity, Journal of Catalysis, 2 (1963) 371-379.

[55] J.F. Haw, Zeolite acid strength and reaction mechanisms in catalysist, Physical Chemistry Chemical Physics, 4 (2002) 5431-5441.

[56] M.W. Erichsen, S. Svelle, U. Olsbye, The influence of catalyst acid strength on the methanol to hydrocarbons (MTH) reaction, Catalysis Today, 215 (2013) 216-223.

[57] B. Civalleri, E. Garrone, P. Ugliengo, Ab initio study of the adducts of small molecules with the isolated hydroxyl of silica and the Bronsted site in zeolites: A comparison between B3-LYP and MP2 methods, Journal of Physical Chemistry B, 102 (1998) 2373-2382.

[58] S. Savitz, A.L. Myers, R.J. Gorte, Calorimetric investigation of $\mathrm{CO}$ and $\mathrm{N}_{2}$ for characterization of acidity in zeolite H-MFI, Journal of Physical Chemistry B, 103 (1999) 3687-3690.

[59] A. Zecchina, G. Spoto, S. Bordiga, Probing the acid sites in confined spaces of microporous materials by vibrational spectroscopy, Physical Chemistry Chemical Physics, 7 (2005) 1627-1642.

[60] M. Niwa, K. Suzuki, K. Isamoto, N. Katada, Identification and measurements of strong Bronsted acid site in ultrastable Y (USY) zeolite, Journal of Physical Chemistry B, 110 (2006) 264-269.

[61] T. Noda, K. Suzuki, N. Katada, M. Niwa, Combined study of IRMS-TPD measurement and DFT calculation on Bronsted acidity and catalytic cracking activity of cation-exchanged Y zeolites, Journal of Catalysis, 259 (2008) 203-210.

[62] K. Suzuki, T. Noda, G. Sastre, N. Katada, M. Niwa, Periodic Density Functional Calculation on the Bronsted Acidity of Modified Y-Type Zeolite, Journal of Physical Chemistry C, 113 (2009) 5672-5680.

[63] X.S. Liu, DRIFTS study of surface of gamma-alumina and its dehydroxylation, Journal of Physical Chemistry C, 112 (2008) 5066-5073.

[64] R.D. Shannon, Revised effective ionic-radii and systematic studies of interatomic distances in halides and chalcogenides, Acta Crystallographica Section A, 32 (1976) 751 767.

[65] C. Meyer, V. Hager, W. Schwieger, P. Wasserscheid, Enhanced activity and selectivity in n-octane isomerization using a bifunctional SCILL catalyst, Journal of Catalysis, 292 (2012) 157-165.

[66] Y. Kuwahara, D.Y. Kang, J.R. Copeland, N.A. Brunelli, S.A. Didas, P. Bollini, C. Sievers, T. Kamegawa, H. Yamashita, C.W. Jones, Dramatic Enhancement of $\mathrm{CO}_{2}$ Uptake by Poly(ethyleneimine) Using Zirconosilicate Supports, Journal of the American Chemical Society, 134 (2012) 10757-10760. 
[67] A.S. Mahadevi, G.N. Sastry, Cation-pi Interaction: Its Role and Relevance in Chemistry, Biology, and Material Science, Chemical Reviews, 113 (2013) 2100-2138. [68] K.J. Thomas, R.B. Sunoj, J. Chandrasekhar, V. Ramamurthy, Cation-pi-interaction promoted aggregation of aromatic molecules and energy transfer within $\mathrm{Y}$ zeolites, Langmuir, 16 (2000) 4912-4921.

[69] V. Ramamurthy, J. Shailaja, L.S. Kaanumalle, R.B. Sunoj, J. Chandrasekhar, Controlling chemistry with cations: photochemistry within zeolites, Chemical Communications, (2003) 1987-1999.

[70] H.G. Karge, Y. Zhang, H.K. Beyer, Preparation of bifunctional catalysts by solidstate ion-exchange in zeolites, Catalysis Letters, 12 (1992) 147-156.

[71] M.D. Gonzalez, Y. Cesteros, P. Salagre, Establishing the role of Bronsted acidity and porosity for the catalytic etherification of glycerol with tert-butanol by modifying zeolites, Applied Catalysis a-General, 450 (2013) 178-188.

[72] V.V. Ordomsky, J. van der Schaaf, J.C. Schouten, T.A. Nijhuis, Fructose Dehydration to 5-Hydroxymethylfurfural over Solid Acid Catalysts in a Biphasic System, Chemsuschem, 5 (2012) 1812-1819. 